\title{
Economical Production of Recombinant Human Interleukin-17E using Industrially Important Salt Inducible Escherichia coli GJ1158: A Fermentation Approach
}

\author{
Jaya Lakshmi G ${ }^{1}$, Seetha Ram Kotra ${ }^{1}$, PVD Soujanya Kumari ${ }^{2}$, P Balakota Reddy ${ }^{3}$, \\ Raja Challapalli ${ }^{4}$, JB Peravali ${ }^{5}$ and KRS Sambasiva Rao ${ }^{1 *}$ \\ ${ }^{1}$ Department of Biotechnology, Acharya Nagarjuna University, Nagarjuna Nagar, \\ Guntur - 522510, Andhra Pradesh, India \\ ${ }^{2}$ Department of Microbiology, M.V.R. PG College, Andhra University, Visakapatnam- \\ 530026, India \\ ${ }^{3}$ Department of Research and Development, Bioviz Technologies Pvt Ltd, Hyderabad- \\ 500029, India \\ ${ }^{4}$ Division of Neurology, AIMS, Guntur, Andhra Pradesh, India \\ ${ }^{5}$ Department of Biotechnology, Bapatla Engineering College, Bapatla, Guntur, \\ Andhra Pradesh, India \\ *krssrao@yahoo.com
}

\begin{abstract}
Interleukin-17E (also known as Interleukin-25) is the distinct member of Interleukin-17 cytokine family, induces the expression of $I L-4, I L-5$ and $I L-13$. Economical production of interleukin - 17E has lot of importance in the current day research in several clinical applications. The objective of the study was to optimize the physico-chemical parameters i.e., dissolved oxygen (DO) and nutritional factors i.e., carbon, nitrogen and phosphate sources on production of Interleukin-17E using industrially important salt inducible Escherichia coli GJ1158. The expression levels were not increased beyond $30 \%$ DO in batch fermentation, but expression levels were increased beyond $30 \%$ DO in fed-batch fermentation. The threshold level of dissolved oxygen ranges was $50 \%$ in respect to the IL-17E production. Pulses of nutritional factors i.e., glucose, yeast extract and $\mathrm{K}_{2} \mathrm{HPO}_{4}$ enhanced the expression levels in fed batch fermentation at $40 \%$ and $50 \%$ dissolved oxygen ranges. When $O D_{600}$ of the culture reaches to 74 in fed batch fermentation, culture was induced with $100 \mathrm{mM}$ sterile $\mathrm{NaCl}$ and further incubated for next $15 \mathrm{hr}$. Purification was carried out using Ni-NTA spin column. A final concentration of $98 \mathrm{mg} / \mathrm{L}$ of purified $I L-17 E$ was obtained using cost effective medium viz., modified M9ON medium. The IL-17E thus produced is tested for its activity. In this study, fed-batch fermentation emphasizes the highest concentration of codon optimized recombinant human interleukin-17E using salt inducible expression host till to date, which manages to satisfy the industrial and clinical requirements.
\end{abstract}

Keywords: Interleukin-25, physico-chemical parameters, dissolved oxygen, threshold levels, fed batch fermentation

\footnotetext{
${ }^{*}$ Corresponding Author
} 


\section{Introduction}

Deregulated and excessive immune reactivity within the intestinal wall against luminal antigens results inflammatory bowel disease (IBD) [1]. The cytokines of IL-17 family induces the production of pro-inflammatory cytokines and play similar roles in the development of certain diseases, but not IL-17E and it has unique abilities in regulating Th2 cell-type immune responses. On the other hand it plays a decisive role both in the induction of a protective response against parasites and in the initiation of innate and adaptive pro-allergic responses [2]. IL-17E belongs to IL-17 was found to accumulate in polarized Th2 cells [3], primary bone marrow-derived mast cells upon IgE cross-linking [4], eosinophils and basophiles upon stem cell factor stimulation [5], lung epithelial cells upon allergic response [6], and alveolar macrophages after particle inhalation [7], intestinal epithelial cells and brain capillary endothelial cells [8]. IL-17E also has anti-tumor [9] and anti-inflammatory activities [10]. Based on the literature, the recombinant human IL-17E was produced in small scale using recombinant adenovirus or cell lines like human embryonic kidney (HEK) 293 cells or Sf9 insect cells [11]. Commercial production is only possible with prokaryotic system.

Escherichia coli are the most prominent host system for the production of industrially important enzymes and bio-therapeutics. Now a day, an r-DNA technology and fermentation approach allows large-scale production of industrially important bio-therapeutics at higher concentrations, because the native production is not satisfying the industrial needs. For the effective large scale production, the parameters like plasmid stability [12], strong promoters [13], protein secretion without signal sequence [14] and the short-term of production time using recombinant cultures [15] was desirable. In this study, the salt inducible E. coli GJ1158 was used for the economical production of codon optimized interleukin-17E.

\section{Materials and Methods}

\subsection{Bacterial Strains and Culture Conditions}

Escherichia coli GJ1158 was used as the expression host for the production of Interleukin17E, was procured from Genei, Bangalore. Antibiotic-kanamycin was procured from Novagen and $50 \mu \mathrm{g} / \mathrm{mL}$ of kanamycin was used as a selection marker in all types of fermentation trails.

LBON medium (Tryptone $-10 \mathrm{~g} / \mathrm{L}$ and Yeast extract $-5 \mathrm{~g} / \mathrm{L}$ ) and Modified M9ON medium $\left(\mathrm{K}_{2} \mathrm{HPO}_{4}-8 \mathrm{~g} / \mathrm{L}, \mathrm{KH}_{2} \mathrm{PO}_{4}-3 \mathrm{~g} / \mathrm{L}, \mathrm{NH}_{4} \mathrm{Cl}-1 \mathrm{~g} / \mathrm{L}\right.$, Yeast extract $-20 \mathrm{~g} / \mathrm{L}$, glucose $10 \mathrm{~g} / \mathrm{L}, 1 \mathrm{M} \mathrm{MgSO}_{4}-2 \mathrm{~mL}, \mathrm{TMM}-1 \mathrm{~mL}\left(\mathrm{Al}_{2}\left(\mathrm{SO}_{4}\right)_{3} .7 \mathrm{H}_{2} \mathrm{O}-10 \mathrm{mg} / \mathrm{L}, \mathrm{CuSO}_{4} . \mathrm{H}_{2} \mathrm{O}-2\right.$ $\mathrm{mg} / \mathrm{L}, \mathrm{H}_{3} \mathrm{BO}_{4}-1 \mathrm{mg} / \mathrm{L}, \mathrm{MnCl}_{3} .4 \mathrm{H}_{2} \mathrm{O}-20 \mathrm{mg} / \mathrm{L}, \mathrm{NiCl}_{2} .6 \mathrm{H}_{2} \mathrm{O}-1 \mathrm{mg} / \mathrm{L}, \mathrm{Na}_{2} \mathrm{MoO}_{4} \cdot 2 \mathrm{H}_{2} \mathrm{O}-$ $50 \mathrm{mg} / \mathrm{L}, \mathrm{ZnSO}_{4} .7 \mathrm{H}_{2} \mathrm{O}-50 \mathrm{mg} / \mathrm{L}, \mathrm{FeSO}_{4}-50 \mathrm{mg} / \mathrm{L}$ ) was used in this study. All chemicals and media ingredients were procured from Hi- Media Limited, Mumbai, India. $\mathrm{NaCl}$ was excluded from medium composition while working with Escherichia coli GJ1158. Culture OD was determined at $600_{\mathrm{nm}}$.

\subsection{Preparation of Inoculum}

The rhIL-17E pET28 ${ }^{\mathrm{a}+}$ E. coli BL21 (DE3) was constructed in our lab (data not shown here) and the recombinant culture was stored at $-20{ }^{\circ} \mathrm{C}$ using glycerol aliquotes. The recombinant plasmid has strong promoter. The r-DNA was isolated and transformed into salt inducible E. coli GJ1158 for further studies. Before starting the experiment, $2 \%$ glycerol stock was added to LBON plate (kanamycin concentration was $50 \mu \mathrm{g} / \mathrm{ml}$ ) and incubated at 37 ${ }^{0} \mathrm{C}$ for $16-24$ hrs. A single colony was transferred to $100 \mathrm{ml}$ of modified M9ON medium with appropriate antibiotic and incubated at $37{ }^{\circ} \mathrm{C}$ for $4-6 \mathrm{hrs}$ on rotary shaker. 


\subsection{Shake Flask Fermentation}

In shake flask fermentation, $5 \%$ of freshly grown overnight inoculum was added to the 50 $\mathrm{ml}$ of modified M9ON medium aseptically and incubated on a rotary shaker at $37{ }^{\circ} \mathrm{C}$ and 150 $\mathrm{rpm}$. When the cell density $\left(\mathrm{OD}_{600}\right)$ reaches to $1.8 \pm 0.2,100 \mathrm{~mm}$ sterile $\mathrm{NaCl}$ was added aseptically and incubated on a rotary shaker at $37{ }^{\circ} \mathrm{C}$ and $150 \mathrm{rpm}$ for $4 \mathrm{hrs}$.

\subsection{Fermentation}

Fermentation trials were conducted using 10 L Bioflo 3000 (New Brunswick Scientific, Edison, NJ) bioreactor. Sterile $5 \mathrm{~N} \mathrm{NaOH}$ (Sodium hydroxide) and $3 \mathrm{~N}_{2} \mathrm{SO}_{4}$ (Sulphuric acid) were used to control $\mathrm{pH}$ of the medium. For both, batch and fed batch cultivations, different stocks ( $20 \%$ glucose, $10 \% \mathrm{~K}_{2} \mathrm{HPO}_{4}$ and trace metal mix) were prepared. Before addition of inoculum to the fermentor vessel, stocks were added in appropriate amounts. Later feed bottles, $\left(20 \%\right.$ glucose, $50 \%$ yeast extract and $\left.10 \% \mathrm{~K}_{2} \mathrm{HPO}_{4}\right)$ were attached under aseptic conditions. Sterile polypylene glycol (PPG) was used to prevent foam formation during fermentation.

Batch cultivation was carried out in a $3 \mathrm{~L}$ or a $5 \mathrm{~L}$ working volume bioreactor. $\mathrm{pH}$ of the medium (Modified M9 medium) was adjusted to 7.0 by using 5M sodium hydroxide solution, later the medium was sterilized without the addition of trace elements. Sterile filtered trace elements were transferred to the reactor aseptically before inoculation at room temperature. Dissolved oxygen (DO) was measured with a sterile DO probe. The $\mathrm{pH}$ was measured with a sterile probe and maintained constantly using $5 \mathrm{M} \mathrm{NaOH}$ solution and $3 \mathrm{~N}$ sulphuric acid. Fermentor cultivation temperature was set to $37{ }^{\circ} \mathrm{C}$. Agitation was provided by centrally located six-bladed Rushton impellers. The constant aeration rate was $1 \pm 0.25$ vvm dry air. In batch fermentation, induction was carried out with $100 \mathrm{~mm} \mathrm{NaCl}$ when the cell density $\left(\mathrm{OD}_{600}\right)$ of batch culture reaches to 10.5 in modified M9ON medium and 14 to LBON medium at $30 \%$ DO ( 7-8 hrs). After induction, the culture was incubated for further $4-5 \mathrm{hrs}$. The dissolved oxygen percentage was maintained at 30 (before and after induction) by cascading agitation rate $(500-750 \mathrm{rpm})$.

Following the complete consumption of nutritional ingredients, the batch cultivations were switched towards fed batch cultures. Induction was carried when the $\mathrm{OD}_{600}$ of the culture reaches to 74 ( $12-15$ hours). Different DO ranges were maintained as the set point by cascading reaction. Oxygen enrichment was recorded as percentage of pure oxygen added to the total air/gas (taken as 100\%) supplied for aeration [16]. After three hours of inoculation, a pulse of glucose, yeast extract and $\mathrm{K}_{2} \mathrm{HPO}_{4}$ was given to improve the cell density. While giving the pulse the dry cell weight of the culture was calculated and appropriate concentration of sterile inducer $(100 \mathrm{mM} \mathrm{NaCl})$ was added when OD of the culture reaches to 74. The rate of pulse of three components gradually reduced to $75 \%$ for first three hours, 50

$\%$ for the next three hours, $25 \%$ for the next three hours and at the 0 feed rate at the last six hours of post induction.

Glucose levels in the medium was determined by 3, -dinitrosalicylic acid (DNS) method [17]. After induction, cell pellet was dissolved in phosphate buffered saline (PBS) followed by the addition of sample solubilizing buffer $(0.0625 \mathrm{M}$ Tris - $\mathrm{HCl}(\mathrm{pH} 6.8), 5 \% \beta$ Mercaptoethanol, $2 \%$ SDS, $10 \%$ glycerol, $0.01 \%$ bromophenol blue). Samples were analyzed on $12 \%$ SDS-PAGE against low range protein marker. To investigate both the soluble and insoluble fractions, cells were lysed by sonication [18]. After sonication, the samples were loaded on $12 \%$ SDS-PAGE [19]. 


\subsection{Refolding and Purification of rhIL-17E}

The rhIL-17E was purified by IMAC (immobilized-metal affinity chromatography) for 6X His - tagged protein described according to manufacturer instruction using Ni - NTA spin column (Qiagen, Germany). The intracellular expression in E. coli results the formation of insoluble aggregates or inclusion bodies (IB's), later refolded and purified under standard conditions.

Initial lysis of the cell pellet was carried out with lysis buffer $(7 \mathrm{M}$ urea, $100 \mathrm{~mm}$ $\mathrm{NaH}_{2} \mathrm{PO}_{4}, 100 \mathrm{mM}$ Tris- $\mathrm{HCl}(\mathrm{pH} 8.0)$, benzonase nuclease $(3 \mathrm{U} / \mathrm{ml})$ ). Sonication was carried out at $50 \mathrm{~W}$ intermittently in $20 \mathrm{sec}$ on/off cycle for $5 \mathrm{~min}$. Centrifuge the sample at 13,800 rpm for $10 \mathrm{~min}$ at RT. On the other hand, Ni-NTA colomn was equilibrated with lysis buffer. The collected supernatant was transferred to a Ni-NTA spin column and incubated on spin column for $5 \mathrm{~min}$ at RT followed by centrifugation for $2 \mathrm{~min}$ at $5000 \mathrm{rpm}$. Now the column was washed with wash buffer ( $8 \mathrm{M}$ urea, $100 \mathrm{~mm} \mathrm{NaH} \mathrm{PO}_{4}, 100 \mathrm{~mm}$ Tris- $\mathrm{HCl}, \mathrm{pH} 6.3$ ) twice, at $1000 \mathrm{rpm}$ for $5 \mathrm{~min}$. Protein was eluted with elution buffer $(8 \mathrm{M}$ urea, $100 \mathrm{~mm}$ $\mathrm{NaH}_{2} \mathrm{PO}_{4}, 100 \mathrm{~mm}$ Tris- $\mathrm{HCl}, \mathrm{pH} 4.5$ ) at $5000 \mathrm{rpm}$ for $2 \mathrm{~min}$. The rhIL-17E concentration was determined according to Lowry's method using bovine serum albumin (BSA) as a standard [20].

\subsection{Biological Activity of rhIL-25}

The activity of rhIL-17E was determined by the amount of IL-6, released from PBMC (Peripheral Blood Mononuclear Cells) treated with IL-17E. To isolate the PBMC, $10 \mathrm{ml}$ of citrated blood was centrifuged at $1000 \mathrm{rpm}$ for $5 \mathrm{~min}$ at room temperature (RT). Blood plasma was diluted thrice in DPBS with respect to the starter volume. On the other hand, 10 $\mathrm{ml}$ of ficoll hypaque solution was taken. Gently overlay diluted blood sample on $50 \mathrm{ml}$ ficoll hypaque and centrifuge at $500 \mathrm{rpm}$ for $20 \mathrm{~min}$ at RT. PBMC was collected from inter phase of PBS/ficoll hypaque solution and add $5 \mathrm{ml} \mathrm{RBC} \mathrm{lysis} \mathrm{solution} \mathrm{to} \mathrm{pellet} \mathrm{and} \mathrm{incubate} \mathrm{with}$ mixing for every 5 min at RT. Dilute the cells to starter volume with DPBS and centrifuge at $500 \mathrm{rpm}$ for $5 \mathrm{~min}$ at RT. Count the cells with the hemocytometer and determine the cell viability.

After resuspention, transfer the cells to cryovial to store in liquid $\mathrm{N}_{2}$ or use directly for analysis. $5 \times 10^{5}$ PBMC cells were plated into 96 well plates in $100 \mu \mathrm{L}$ of culture medium. Recombinant human IL-25 purchased from R\&D systems, USA used as standard. PBMC cells were treated with various concentrations of human IL-25 to generate the proper standard curve. PBMCs were treated with different concentrations viz., $3.9 \mathrm{ng} / \mathrm{ml}, 7.8 \mathrm{ng} / \mathrm{ml}, 15.6$ $\mathrm{ng} / \mathrm{ml}, 31.25 \mathrm{ng} / \mathrm{ml}, 62.5 \mathrm{ng} / \mathrm{ml}, 125 \mathrm{ng} / \mathrm{ml}, 250 \mathrm{ng} / \mathrm{ml}, 500 \mathrm{ng} / \mathrm{ml}$ and $1000 \mathrm{ng} / \mathrm{ml}$ of $\mathrm{rhIL}-$ $17 \mathrm{E}$ for 72 hours. Sample was added to the cells in $100 \mu \mathrm{L}$ of culture medium.

\section{Results and Discussion}

\subsection{Shake Flask Cultivation}

Production of rhIL-17E was evaluated using recombinant salt inducible E. coli GJ1158 at shake flask level in both LBON and modified M9ON medium The protein expression was observed using $12 \%$ SDS-PAGE. In modified M9ON medium, the recombinant protein specific yield was $2 \mathrm{mg} / \mathrm{L}$ and in LBON medium, the specific yield is $8 \mathrm{mg} / \mathrm{L}$ respectively. Expression is 4 times higher in complex medium than synthetic medium.

\subsection{Batch Fermentation}

Based on the results of shake flask studies, recombinant protein expression was higher in LBON broth when compared to modify M9ON medium. But economical production is only 
possible with cost effective media. Hence, batch cultivation was performed using LBON medium and modified M9ON medium in a $10 \mathrm{~L}$ bioreactor with a working volume of $5 \mathrm{~L}$ at different dissolved oxygen concentrations like, 10, 20 and 30\% (Figure 1).

At a final $\mathrm{OD}_{600}(\sim 10.5)$ in modified M9ON medium and ( 14) in LBON medium at $30 \%$ DO (Figure - 2), culture was induced with $100 \mathrm{~mm} \mathrm{NaCl}$ and followed by $3-4 \mathrm{hrs}$ of post induction process. The specific yield was $38 \mathrm{mg} / \mathrm{L}$ and $46 \mathrm{mg} / \mathrm{L}$ in modified M9ON medium and LBON medium respectively. The production ranges using LBON and modified M9ON medium were elevated compared with shake flask fermentation. No prominent results were observed even after the DO was enhanced beyond $30 \%$.
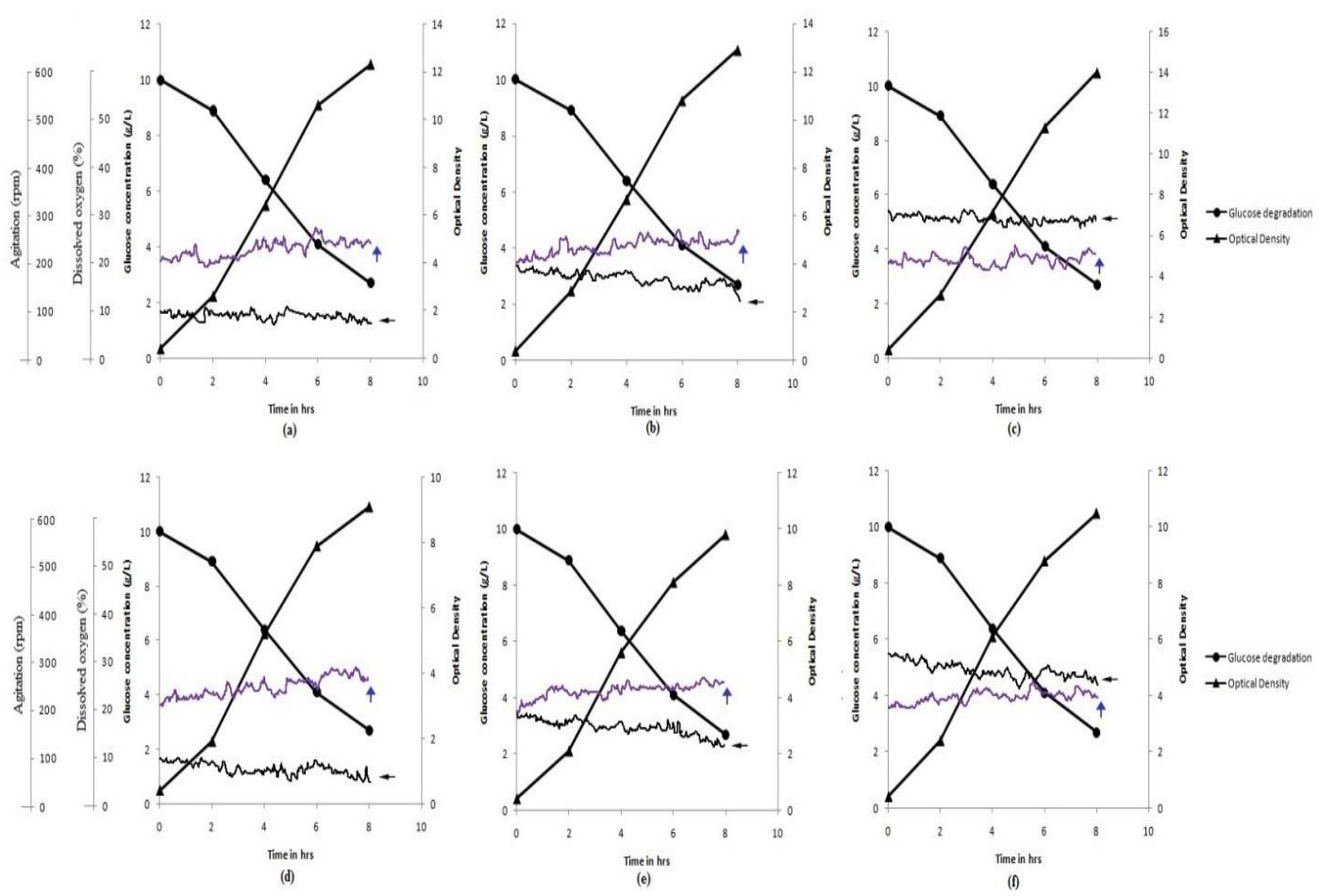

Figure 1. (a). Batch Fermentation at $10 \%$ Dissolved Oxygen using LBON Medium

(b). Batch Fermentation at 20\% Dissolved Oxygen using LBON Medium

(c). Batch Fermentation at 30\% Dissolved Oxygen using LBON Medium

(d). Batch Fermentation at $10 \%$ Dissolved Oxygen using Modified M9ON Medium

(e). Batch Fermentation at 20\% Dissolved Oxygen using Modified M9ON Medium

(f). Batch Fermentation at 30\% Dissolved Oxygen using Modified M9ON Medium

Black color arrow indicating DO supply, Blue color arrow indicating the agitation.

\subsection{Fed Batch Fermentation}

Fed-batch cultivations were carried out after complete consumption of nutrients like glucose, $\mathrm{K}_{2} \mathrm{HPO}_{4}$ and yeast extract in batch fermentation. To build up high cell density, carbon, nitrogen and phosphate content in media composition are essential and is directly 
proportional to the protein production. The effect of dissolved oxygen ranges $30,40,50$ and $60 \%$ were studied on production of rhIL-17E. The fed-batch fermentation at 30, 40 and $50 \%$ dissolved oxygen under nutrients supply before and after induction gave maximum yield. Culture was induced with $100 \mathrm{mM} \mathrm{NaCl}$ when the $\mathrm{OD}_{600}$ of the culture reaches to 74 (after 18 hrs). The produced recombinant protein is also having biological activity.

\subsubsection{Effect of Carbon Pulse}

Carbon source was the major constituent for synthesis of cellular material and also for the enzyme production [21,22]. Carbon content in the medium was reduced when culture reaches to stationary phase [23]. To improve the cell density and production yield in fed batch fermentation, concentration of glucose in medium was maintained as $10 \mathrm{~g} / \mathrm{L}$ up to induction process. A pulse of glucose like $2.1 \mathrm{~g} / \mathrm{L} / \mathrm{h}$ for first 5 hours and $4.3 \mathrm{~g} / \mathrm{L} / \mathrm{h}$ for next 10 hours at $30 \% \mathrm{DO}, 2.6 \mathrm{~g} / \mathrm{L} / \mathrm{h}$ for first 5 hours and $4.8 \mathrm{~g} / \mathrm{L} / \mathrm{h}$ for next 10 hours at $40 \%$ DO and $3.2 \mathrm{~g} / \mathrm{L} / \mathrm{h}$ for first 5 hours and $5.4 \mathrm{~g} / \mathrm{L} / \mathrm{h}$ for next 10 hours at $50 \%$ DO was provided for increased cell density (Figure -2 ). No significant difference in OD was observed at $18^{\text {th }}$ and $19^{\text {th }}$ hour. At $30 \%$ DO, glucose as pulse in modified M9ON medium yields $69 \mathrm{mg} / \mathrm{L}$ of recombinant protein, at $40 \% \mathrm{DO}$, glucose as pulse yields $72 \mathrm{mg} / \mathrm{L}$ of recombinant protein and at $50 \%$ DO, glucose as pulse in modified M9ON medium yields $78 \mathrm{mg} / \mathrm{L}$ of recombinant protein.

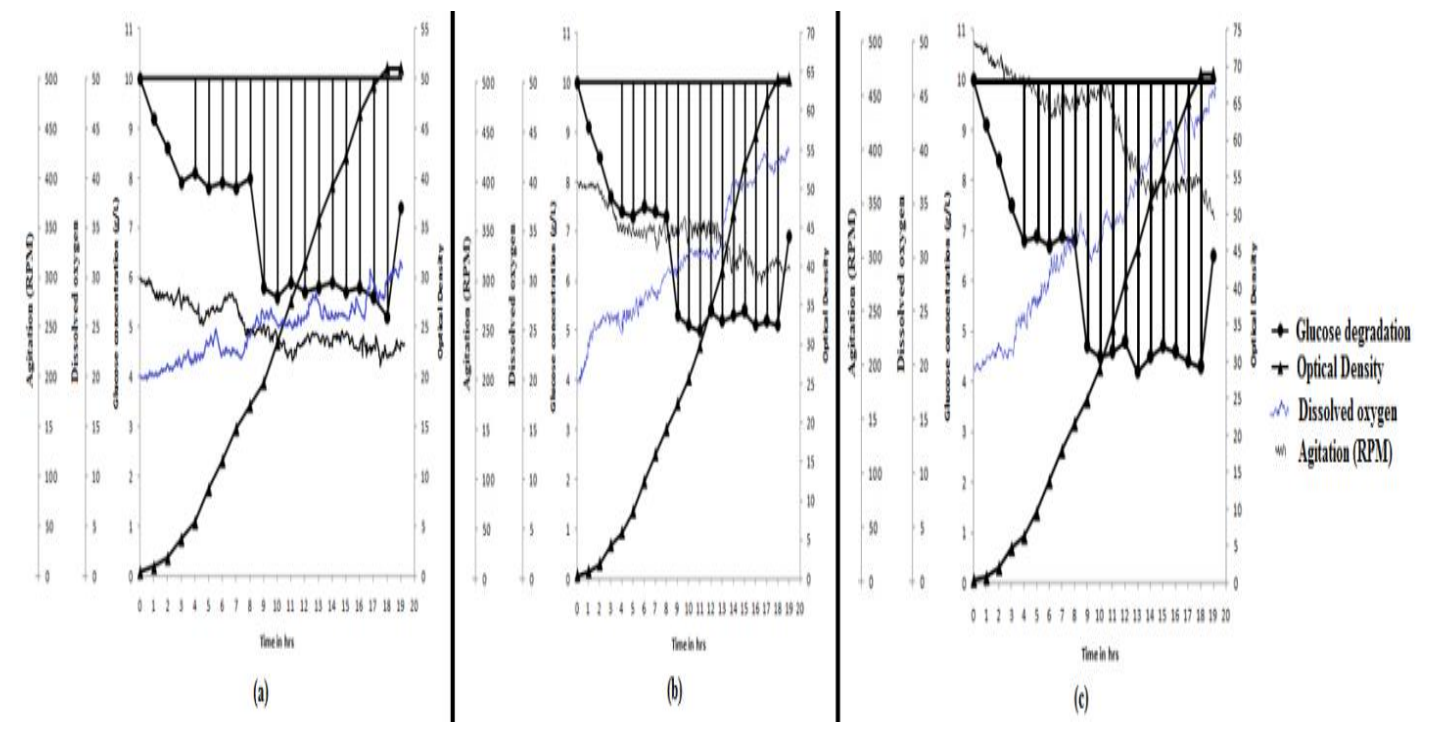

Figure 2. (a). Effect of Carbon Pulse at $30 \%$ Dissolved Oxygen in Fed Batch Fermentation using Modified M9ON Medium

(b). Effect of Carbon Pulse at 40\% Dissolved Oxygen in Fed Batch Fermentation using modified M9ON Medium

(c). Effect of Carbon Pulse at 50\% Dissolved Oxygen in Fed Batch Fermentation using Modified M9ON Medium

Vertical lines indicating the addition of carbon pulse to maintain $10 \mathrm{~g} / \mathrm{L}$ up to induction process.

\subsubsection{Effect of Nitrogen Pulse}

Nitrogen source is also one of the key components to synthesize the proteins for its survival [24]. Out of different nitrogen sources, yeast extract is the major nutrient for the high cell density and protein production [25]. To over express the rhIL-17E, the effect of different 
nitrogen sources were investigated on bacterial growth as it resulted in increased recombinant protein expression [26-28]. The continuous pulse of nitrogen source results the highest specific protein concentration [29-31]. A pulse of yeast extract like $5 \mathrm{~g} / \mathrm{L} / \mathrm{h}$ for first 5 hours and $8.9 \mathrm{~g} / \mathrm{L} / \mathrm{h}$ for next 10 hours at $30 \% \mathrm{DO}, 5.4 \mathrm{~g} / \mathrm{L} / \mathrm{h}$ for first 5 hours and $9.4 \mathrm{~g} / \mathrm{L} / \mathrm{h}$ for next 10 hours at $40 \%$ DO and $5.6 \mathrm{~g} / \mathrm{L} / \mathrm{h}$ for first 5 hours and $9.7 \mathrm{~g} / \mathrm{L} / \mathrm{h}$ for next 10 hours at $50 \%$ DO was provided for increased cell density (Figure - 3). No significant difference in OD was observed at $18^{\text {th }}$ and $19^{\text {th }}$ hour. Yeast extract along with glucose as pulse at $30 \%$ DO in modified M9ON medium yields $71 \mathrm{mg} / \mathrm{L}$ of recombinant protein, at $40 \% \mathrm{DO}$, along with glucose as pulse yields $84 \mathrm{mg} / \mathrm{L}$ of rhIL-17E and it is high at $50 \% \mathrm{DO}$, along with glucose as pulse in modified M9ON medium, yields $89 \mathrm{mg} / \mathrm{L}$ of recombinant protein.

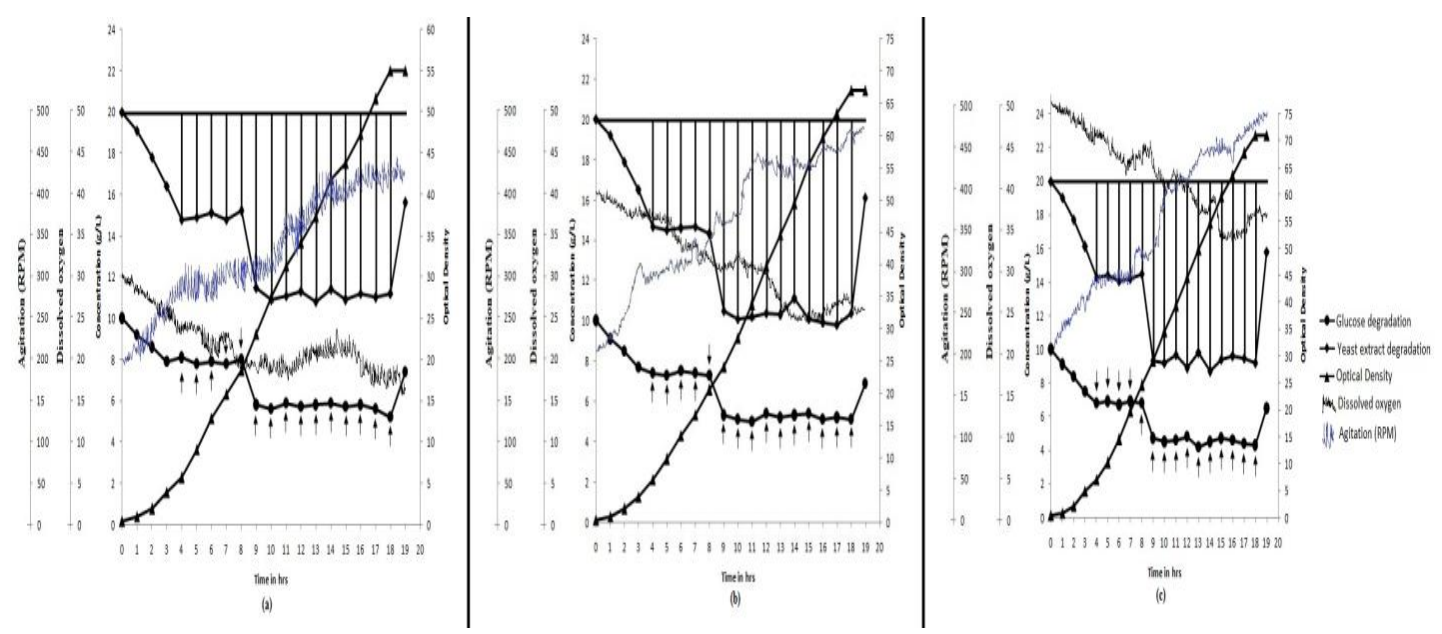

Figure 3. (a). Effect of Nitrogen Pulse at $30 \%$ Dissolved Oxygen in Fed Batch Fermentation using Modified M9ON Medium

(b). Effect of Nitrogen Pulse at $40 \%$ Dissolved Oxygen in Fed Batch Fermentation using Modified M9ON Medium

(c). Effect of Nitrogen Pulse at 50\% Dissolved Oxygen in Fed Batch Fermentation using Modified M9ON Medium

Vertical lines indicating the addition of nitrogen pulse to maintain $20 \mathrm{~g} / \mathrm{L}$ Arrows indicating the addition of carbon pulse to maintain $10 \mathrm{~g} / \mathrm{L}$ up to induction process.

\subsubsection{Effect of Phosphate Pulse}

Next to the carbon and nitrogen, phosphate compounds acts as major nutrients in cell growth followed by protein expression [32]. The feeding rate of $\mathrm{K}_{2} \mathrm{HPO}_{4}$ improves the cell biomass and the protein production [33]. Some studies proved the high concentration of phosphate is important for attaining high-cell densities in E. coli [34]. A pulse of $\mathrm{K}_{2} \mathrm{HPO}_{4}$ like $1.8 \mathrm{~g} / \mathrm{L} / \mathrm{h}$ for first 5 hours and $3.4 \mathrm{~g} / \mathrm{L} / \mathrm{h}$ for next 10 hours at $30 \% \mathrm{DO}, 2.2 \mathrm{~g} / \mathrm{L} / \mathrm{h}$ for first 5 hours and $3.9 \mathrm{~g} / \mathrm{L} / \mathrm{h}$ for next 10 hours at $40 \% \mathrm{DO}$ and $2.6 \mathrm{~g} / \mathrm{L} / \mathrm{h}$ for first 5 hours and $4.3 \mathrm{~g} / \mathrm{L} / \mathrm{h}$ for next 10 hours at $50 \%$ DO was provided for increased cell density (Figure -4 ). No significant difference in OD was observed at $18^{\text {th }}$ and $19^{\text {th }}$ hour. While giving the pulse the dry weight of the biomass was determined and appropriate concentration of inducer is added $(150 \mathrm{~mm} \mathrm{NaCl})$ when the OD reaches to 74 at $50 \% \mathrm{DO}$. After induction, the rate of pulse will gradually reduced to $75 \%$ for first $2 \mathrm{hrs}, 50 \%$ for the next 2 hours, and $25 \%$ for the next $2 \mathrm{hrs}$ and at the 0 feed rate at the last $2 \mathrm{hrs}$ of post induction. At $30 \% \mathrm{DO}$, phosphate pulse on combination with glucose and nitrogen pulses in modified M9ON medium yields $83 \mathrm{mg} / \mathrm{L}$ of 
recombinant protein, at $40 \% \mathrm{DO}$, phosphate pulse on combination with glucose and nitrogen pulses in modified M9ON medium yields $92 \mathrm{mg} / \mathrm{L}$ of recombinant protein and at $50 \% \mathrm{DO}$, phosphate pulse on combination with glucose and nitrogen pulses in modified M9ON medium yields $98 \mathrm{mg} / \mathrm{L}$ of recombinant protein.

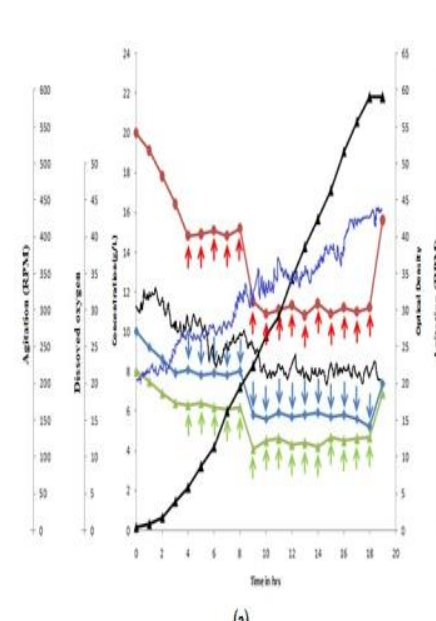

(a)

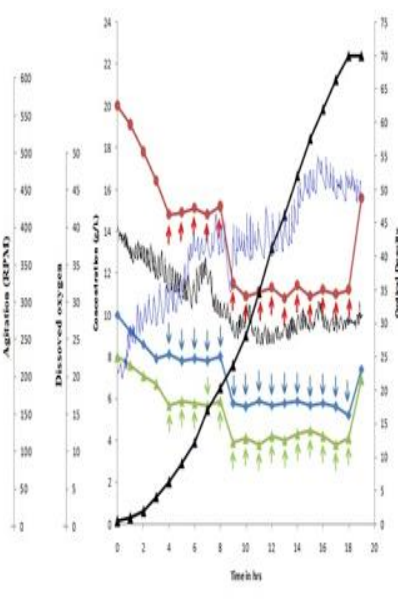

(b)

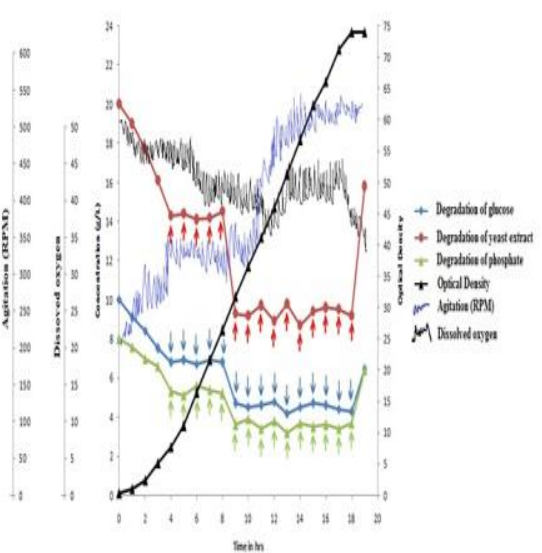

(c)

Figure - 4: (a). Effect of Phosphate Pulse at 30\% Dissolved Oxygen in Fed Batch Fermentation using Modified M9ON Medium

(b). Effect of Phosphate Pulse at $40 \%$ Dissolved Oxygen in Fed Batch Fermentation using Modified M9ON Medium

(c). Effect of Phosphate Pulse at 50\% Dissolved Oxygen in Fed Batch Fermentation using Modified M9ON Medium

Blue color arrows indicating the addition of carbon pulse to maintain $10 \mathrm{~g} / \mathrm{L}$, red color arrows indicating the addition of nitrogen pulse to maintain $20 \mathrm{~g} / \mathrm{L}$ and green color arrows indicating the addition of phosphate pulse to maintain $8 \mathrm{~g} / \mathrm{L}$ up to induction process

\subsubsection{Effect of Dissolved Oxygen (DO)}

In some circumstances, dissolved oxygen is also considered as a nutrient. Fed batch fermentation was carried out with different dissolved oxygen ranges like 30, 40 and 50\%. No progressive production was observed beyond $30 \%$ DO in batch fermentation. On supplementation of nutrients pulses in fed batch at 50\% DO results the increased protein production. According to Genshen Zhong, et al., (2009) 20\% dissolved oxygen is enough to produce the recombinant proteins at large scale in fed batch cultivation [35]. In some studies $10 \%$ DO is enough to produce the protein [36]. According to Antonino Baez and Joseph Shiloach (2013) $30-300 \%$ DO is enough to produce the proteins in large scale using parental strains [37]. But the bacterial cell growth is very low at 300\% DO using mutated or recombinant cultures. By keeping the threshold levels of bacteria in order to maintain DO, the next fed-batch cultivation is carried out at $40 \%$ and $50 \%$ DO.

Cell growth and protein production was enhanced in fed batch fermentation at 50\% DO when compared to fed-batch fermentation at $30 \%$ DO. The cell density was not increased after post induction process. At $50 \%$ DO using glucose, yeast extract and $\mathrm{K}_{2} \mathrm{HPO}_{4}$ pulses, the recombinant human $\mathrm{IL}-17 \mathrm{E}$ was produced at a concentration of $98 \mathrm{mg} / \mathrm{L}$. At $60 \% \mathrm{DO}$ in fed batch fermentation, growth and production of rhIL-17E was not appreciable. The initial postinduction time is crucial for the expression of recombinant protein under the strong promoter 
T7 as product formation ceased after few hours of induction period [38]. The low and high levels of DO are not unusual and supposed to happen due to changes in nutrient uptake of bacteria [39], aeration or agitation rates [40]. In this study, we proved the nutrient uptake was also influenced by dissolved oxygen in salt inducible E. coli. Production of recombinant protein at different DO ranges respect to different fermentation levels was mentioned in the following Table 1.

Table 1. Recombinant Human IL-17E at Different Stages of Production

\begin{tabular}{|c|c|c|c|}
\hline Cultivation type & Medium used & $\mathrm{OD}_{600}{ }^{1}$ & $\begin{array}{l}\text { Recombinant human } \\
\text { IL-17E (mg/L) }\end{array}$ \\
\hline Flask & LBON & 2.1 & 8 \\
\hline Flask & MM9ON & 1.9 & 2 \\
\hline Batch (10\% DO) & LBON & 12.3 & 28 \\
\hline Batch (10\% DO) & MM9ON & 9.1 & 21 \\
\hline Batch (20\% DO) & LBON & 12.9 & 38 \\
\hline Batch (20\% DO) & MM9ON & 9.8 & 30 \\
\hline Batch (30\% DO) & LBON & 14 & 46 \\
\hline Batch (30\% DO) & MM9ON & 10.5 & 38 \\
\hline Fed batch $(30 \% \mathrm{DO})$ & MM9ON + glucose as pulse & 51 & 69 \\
\hline Fed batch $(30 \%$ DO) & $\begin{array}{c}\text { MM9ON + glucose and Yeast } \\
\text { extract as pulse }\end{array}$ & 55 & 71 \\
\hline Fed batch $(30 \%$ DO) & $\begin{array}{l}\text { MM9ON }+ \text { glucose, Yeast extract } \\
\text { and } \mathrm{K}_{2} \mathrm{HPO}_{4} \text { as pulse }\end{array}$ & 59 & 83 \\
\hline Fed batch $(40 \%$ DO) & MM9ON + glucose as pulse & 64 & 72 \\
\hline Fed batch $(40 \%$ DO) & $\begin{array}{c}\text { MM9ON + glucose and Yeast } \\
\text { extract as pulse }\end{array}$ & 67 & 84 \\
\hline Fed batch $(40 \%$ DO) & $\begin{array}{l}\text { MM9ON + glucose, Yeast extract } \\
\text { and } \mathrm{K}_{2} \mathrm{HPO}_{4} \text { as pulse }\end{array}$ & 70 & 92 \\
\hline Fed batch $(50 \%$ DO) & MM9ON + glucose as pulse & 69 & 78 \\
\hline Fed batch $(50 \%$ DO) & $\begin{array}{c}\text { MM9ON + glucose and Yeast } \\
\text { extract as pulse }\end{array}$ & 71 & 89 \\
\hline Fed batch $(50 \%$ DO) & $\begin{array}{l}\text { MM9ON + glucose, Yeast extract } \\
\text { and } \mathrm{K}_{2} \mathrm{HPO}_{4} \text { as pulse }\end{array}$ & 74 & 98 \\
\hline
\end{tabular}

${ }^{1}$ value is \pm means of two independent experiments

\subsection{Purification and Activity of rhIL-17E}

The recombinant IL-17E was expressed in E. coli GJ1158 using salt induction and purified using immobilized-metal affinity chromatography (IMAC). The SDS-PAGE (15\%) of sonicated cell lysate induced with $100 \mathrm{~mm} \mathrm{NaCl}$ showed an over expressed protein band with a molecular weight of $32 \mathrm{kDa}$ (Figure 5a). A prominent single protein band was detected on $15 \%$ SDS-PAGE, after IMAC purification (Figure 5b). The molecular weight of rhIL-17E on SDS-PAGE was in reasonable agreement with low molecular weight protein marker. Western blot analysis also revealed the protein confirmation (Figure 6). 


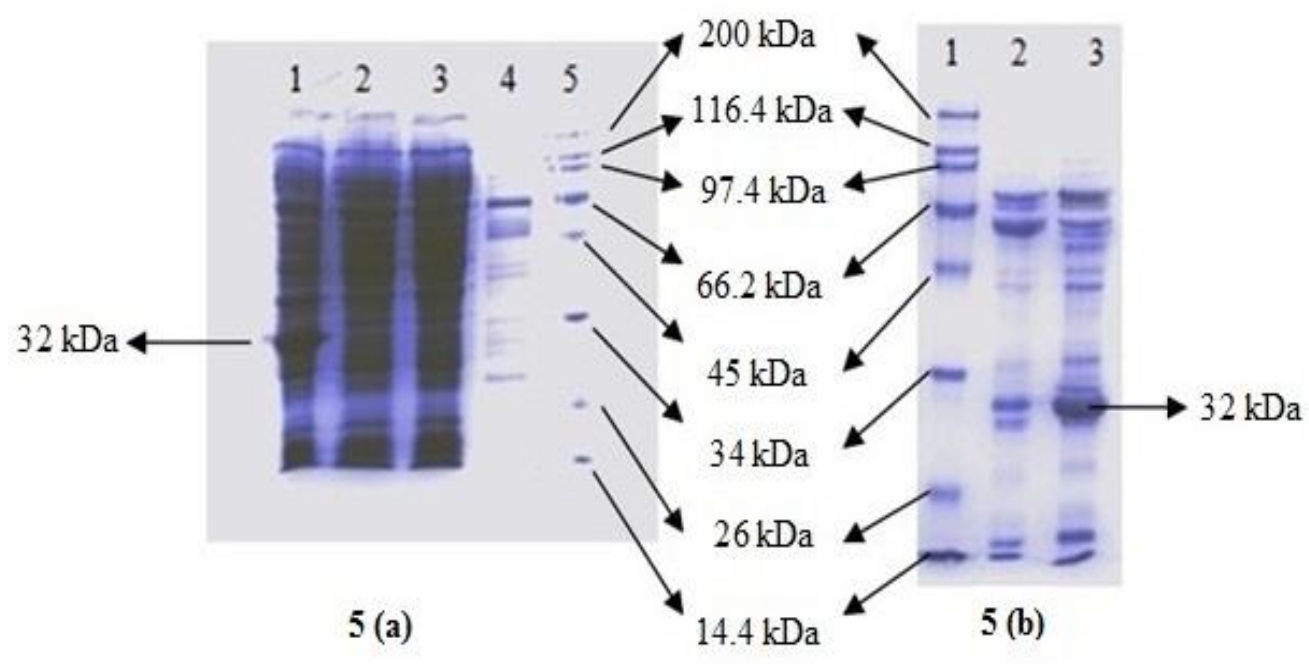

Figure 5. SDS PAGE Analysis of IL-25

Figure 5 (a): $1=$ SDS PAGE analysis of induced culture at $37{ }^{\circ} \mathrm{C}$;

$2=$ SDS PAGE analysis of induced culture for soluble expression at $37{ }^{\circ} \mathrm{C}$;

$3=$ SDS PAGE analysis of uninduced culture at $37^{\circ} \mathrm{C}$;

$4=$ SDS PAGE analysis of uninduced culture at $20^{\circ} \mathrm{C}$;

$5=$ Marker protein $(200 \mathrm{kDa}, 116.25,97.4,66.2,45,34,26,14.4 \mathrm{kDa})$.

Figure -5 (b): 1 = Marker protein $(200 \mathrm{kDa}, 116.25,97.4,66.2,45,34,26,14.4 \mathrm{kDa})$;

$2,3=6 \mathrm{X}$ histidine tag purification and refolding of IL-17E

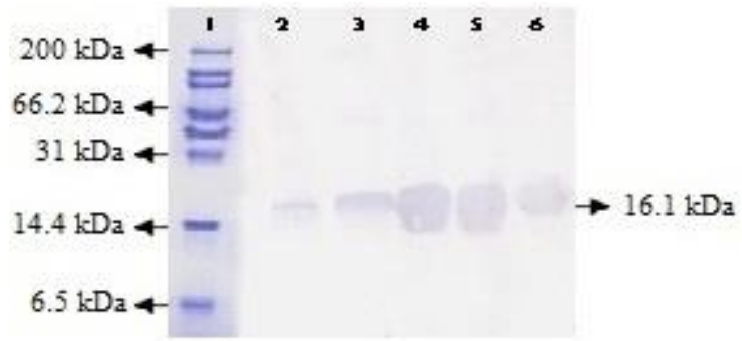

Figure 6. Western Blot Image Showing the Immuno Reactivity of Protein Compared with Reference Protein

$1=$ Marker protein $(200 \mathrm{kDa}, 116.25,97.4,66.2,45,31,14.4,6.5 \mathrm{kDa})$.

$2=$ Purified IL-17E $(0.5 \mu \mathrm{g})$

$3=$ Purified IL-17E $(1 \mu \mathrm{g})$

$4=$ Purified IL-17E $(2 \mu \mathrm{g})$

$5=$ Purified IL-17E $(3 \mu \mathrm{g})$

$6=\mathrm{IL}$ reference protein $(1.5 \mu \mathrm{g})$

Biological activity of human IL-25 was tested as per the standard protocol using human PBMC. The IL-6 levels were estimated in the IL-25 treated cells were shown in the figure 7. After $72 \mathrm{hrs}$ of incubation, the lysate was used to analyze the IL-6 levels by ELISA method using the human IL-6 ELISA kit from Ray Biotech. 


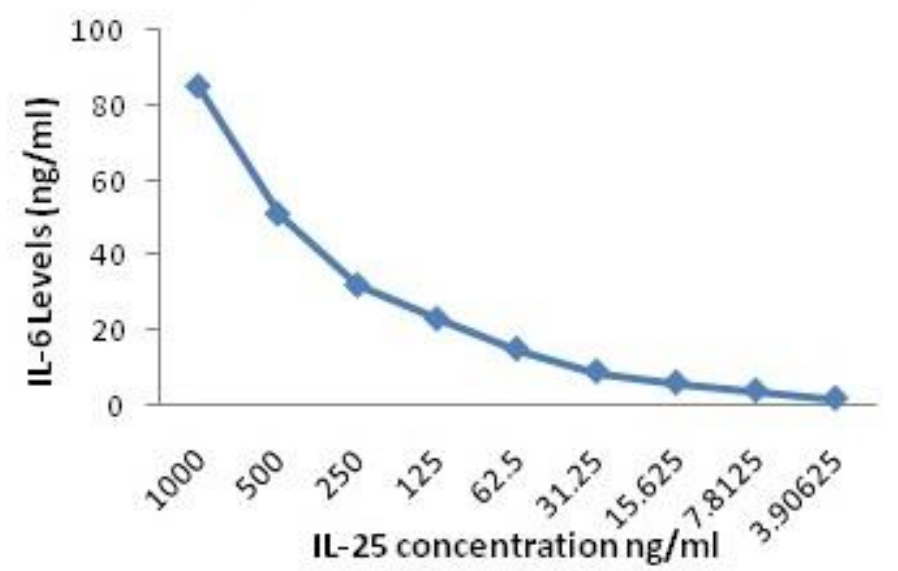

Figure 7. Estimation of IL-6 Levels using PBMC Cells Treated with IL-25

\section{Conclusion}

The new class of interleukin-17E will have huge importance in future because of its activity against different disorders. The codon bias of $E$. coli results the production of IL17E. The optimization of physico-chemical and nutritional parameters leads to the enhanced production of IL-17E was the best of our knowledge from salt inducible Escherichia coli till to date. At flask and batch level the highest quantity of protein was produced from LBON medium. Parallel results were observed using synthetic medium (modified M9ON medium). The final concentration of purified IL-17E produced in this study using salt inducible $E$. coli was high when compared to $39.6 \mathrm{mg} / \mathrm{L}$ of $\mathrm{IL}-17 \mathrm{E}$ [41]. Dissolved oxygen was the most important parameter for the production of IL-17E. At batch level, 1.64 folds increase was observed at $30 \%$ DO over batch fermentation at 10\% DO using LBON medium and 1.8 folds increase was observed at $30 \%$ DO over batch fermentation at $10 \%$ DO using modified M9ON medium.

In fed batch fermentation, 1.43 folds increase was observed by providing the pulse of glucose, yeast extract and $\mathrm{K}_{2} \mathrm{HPO}_{4}$ at $50 \%$ DO using modified M9ON medium over the pulse of only glucose at 30\% DO using modified M9ON medium. The fermentative production of IL-17E using industrially important salt inducible E. coli because it plays an important role to provoke the allergic inflammation, particularly in IgE-dependent atopic diseases and eosinophil-mediated late phase allergic reactions.

\section{Acknowledgements}

Authors are acknowledging their cordial regards to Department of Biotechnology, Acharya Nagarjuna University, Nagarjuna Nagar, Guntur, Andhra Pradesh, India for providing the infrastructure facilities to carry out the work.

\section{References}

[1] W. Strober, I. Fuss and P. Mannon, "The fundamental basis of inflammatory bowel disease", Clin Invest, vol. 117, (2007), pp. 514-521.

[2] G. Monteleone, F. Pallone and T. T. MacDonald, "Interleukin-25: A two edged sword in the control of immune-inflammatory responses", Cytokine Growth Factor Rev., vol. 21, (2010), pp. 471-475. 
[3] M. M. Fort, J. Cheung, D. Yen, J. Li, S. M. Zurawski, S. Lo, S. Menon, T. Clifford, B. Hunte, R. Lesley, T. Muchamuel, S. D. Hurst, G. Zurawski, M. W. Leach, D. M. Gorman and D. M. Rennick, "IL-25 induces IL4, IL-5, and IL-13 and Th2-associated pathologies in vivo", Immunity, vol. 15, (2001), pp. 985-995.

[4] K. Ikeda, H. Nakajima, K. Suzuki, S. Kagami, K. Hirose, A. Suto, Y. Saito and I. Iwamoto, "Mast cells produce interleukin-25 upon Fc epsilon RI-mediated activation", Blood, vol. 101, (2003), pp. 3594-3596.

[5] V. Dolgachev, B. C. Petersen, A. L. Budelsky, A. A. Berlin and N. W. Lukacs, "Pulmonary IL-17E (IL-25) production and IL-17RB(+) myeloid cell-derived Th2 cytokine production are dependent upon stem cell factor-induced responses during chronic allergic pulmonary disease", Immunol, vol. 183, (2009), pp. 57055715.

[6] P. Angkasekwinai, H. Park, Y. H. Wang, Y. H. Wang, S. H. Chang, D. B. Corry, Y. J. Liu, Z. Zhu and C. Dong, "Interleukin 25 promotes the initiation of pro-allergic type 2 responses", Exp Med., vol. 204, (2007), pp. $1509-1517$.

[7] C. M. Kang, A. S. Jang, M. H. Ahn, J. A. Shin, J. H. Kim, Y. S. Choi, T. Y. Rhim and C. S. Park, "Interleukin-25 and interleukin-13 production by alveolar macrophages in response to particles", Am Respir Cell Mol Biol., vol. 33, (2005), pp. 290-296.

[8] Y. Sonobe, H. Takeuchi, K. Kataoka, H. Li, S. Jin, M. Mimuro, Y. Hashizume, Y. Sano, T. Kanda, T. Mizuno and A. Suzumura, "Interleukin-25 expressed by brain capillary endothelial cells maintains bloodbrain barrier function in a protein kinase C epsilon-dependent manner", Biol. Chem., vol. 284, (2009), pp. 31834-31842.

[9] T. Benatar, M. Y. Cao, Y. Lee, J. Lightfoot, N. Feng, X. Gu, V. Lee, H. Jin, M. Wang, J. A. Wright and A. H. Young, "IL-17E, a proinflammatory cytokine, has antitumor efficacy against several tumor types in vivo", Cancer Immunol Immunother, vol. 59, (2010), pp. 805-817.

[10] S. S. Mchenga, D. Wang, C. Li, F. Shan and C. Lu, "Inhibitory effect of recombinant IL-25 on the development of dextran sulfate sodiuminduced experimental colitis in mice", Cell Mol Immunol., vol. 5, (2008), pp. 425-431.

[11] S. D. Hurst, T. Muchamuel, D. M. Gorman, J. M. Gilbert, T. Clifford, S. Kwan, S. Menon, B. Seymour, C. Jackson, T. T. Kung, J. K. Brieland, S. M. Zurawski, R. W. Chapman, G. Zurawski and R. L. Coffman, "New IL-17 family members promote Th1 or Th2 responses in the lung: in vivo function of the novel cytokine IL-25”, Immunol., vol. 169, (2002), pp. 443-453.

[12] F. Silva, J. A. Queiroz and F. C. Domingues, "Evaluating metabolic stress and plasmid stability in plasmid DNA production by Escherichia coli", Biotechnology Adv., vol. 30, no. 3, (2012), pp. 691-708.

[13] N. A Valdez-Cruz, L. Caspeta, N. O. Pérez, O. T. Ramírez and M. A. Trujillo-Roldán, "Production of recombinant proteins in E. coli by the heat inducible expression system based on the phage lambda $\mathrm{pL}$ and/or pR promoters", Microbial Cell Factories, vol. 9, (2010), pp. 18.

[14] M. Sjostrom, S. Wold, A. Wieslander and L. Rilfors, "Signal peptide amino acid sequences in Escherichia coli contain information related to final protein localization. A multivariate data analysis. EMBO J", vol. 6, no. 3, (1987), pp. 823-831.

[15] S. R. Kotra, K. Sobha, V. Viharika, A. P. Kumar, P. V. Rao, M. M. V. Kumari, K. Prasad, G. R. Teja, K. V. Rajesh and J. B. Peravali, "Cloning and high level production of engineered synthetic cationic antimicrobial peptide using methanol inducible Pichia pastoris GS115", International Journal of Bio-Science and BioTechnology, vol. 6, no. 1, (2014), pp. 21-30.

[16] N. N. Dedhia, R. Richins, A. Mesina and W. Chen, "Improvements in recombinant protein production in ppGpp-deficient Escherichia coli”, Biotech. Bioeng, vol. 53, (1997), pp. 379-386.

[17] G. L. Miller, "Use of dinitrosalicylic acid (DNS) for determination of reducing sugars", Anal. Chem., vol. 31, no. 3, (1959), pp. 426-428.

[18] D. Goyal, D. K. Sahoo and G. Sahni, "Hydrophobic interaction expanded bed adsorption chromatography (HI-EBAC) based facile purification of recombinant streptokinase from E. coli inclusion bodies", Chromatogr. B., vol. 850, (2007), pp. 384-391.

[19] J. Sambrook, E. F. Fritsch and T. Maniatis, "Molecular Cloning: a Laboratory Manual. Cold Spring Harbor Laboratory Press, Cold Spring Harbor, New York, USA, (1989), pp. 18.43-18.55.

[20] O. H. Lowry, N. J. Rosebrough, A. L. Farr and R. J. Randall, "Protein measurement with the Folin phenol reagent", Biol Chem., vol. 193, no. 1, (1951), pp. 265-275.

[21] G. M. Dunn, "Nutritional requirements of microorganisms", In: Moo Young, M. (Ed.), Comprehensive Biotechnology, Pergamon Press, Oxford, New York, vol. 1, (1985), pp. 113-125.

[22] S. R. Kotra, N. Prudvi, J. B. Peravali, A. Kumar, K. R. S. Rao and K. K. Pulicherla, "Optimization of media components for the over production and enhanced fibrinolytic activity of recombinant Msak - RGD Hirulog from E. coli GJ1158”, International Journal of Bio-Science and Bio-Technology, vol. 5, no. 3, (2013), pp. 181-197.

[23] K. M. Fagerbakke, M. Heldal and S. Norland, "Content of carbon, nitrogen, oxygen, sulphur and phosphorus in native aquatic and cultured bacteria”, Aquat. Microb, Ecol. Vol. 10, (1996), pp. 15-27. 
[24] H. C. Dube, "Nutrition of Fungi", In: An Introduction to Fungi, H.C. Dube (Ed.), Vicks Publishing House Pvt. Ltd., India, (1983), pp. 481-507.

[25] S. R. Kotra, A. Kumar, K. R. S. S. and K. K. Pulicherla, "Statistical Optimization of media components for enhanced production of the recombinant staphylokinase variant from salt inducible E. coli GJ1158", International Journal of Bio-Science and Bio-Technology, vol. 4, no. 4, (2012), pp. 27-40.

[26] D. H. Kweon, N. S. Han, K. M. Park and J. H. Seo, "Over production of Phytolaccainsularis protein in batch and fed-batch culture of recombinant Escherichia coli”, Process Biochem., vol. 36, (2001), pp. 537-542.

[27] D. W. Zabriskie, D. A. Wareheim and M. J. Polansky, "Effect of fermentation feeding strategies prior to induction of expression of a recombinant malaria antigen Escherichia coli”, Ind. Microbiol., vol. 2, (1987), pp. 87-95.

[28] X. Li, J. W. Robbins Jr. and K. B. Taylor, "The production of recombinant betagalactosidase in Escherichia coli in yeast extract enriched medium", Ind. Microbiol, vol. 5, (1990), pp. 85-94.

[29] H.-L. Jiang, Q. He, Z. He, C. L. Hemme, L. Wu and J. Zhou, "Continuous cellulosic bioethanol fermentation by cyclic fed-batch co-cultivation, Applied and Environmental Microbiology", Published online ahead of print, (2012).

[30] R. Fike, "Nutrient supplementation strategies for biopharmaceutical production, part 2: feeding for optimal recombinant protein production", BioProcess Int., vol. 7, no. 11, (2009), pp. 46-52.

[31] J. P. Carter, "Introduction to current and future protein therapeutics: A protein engineering perspective", Experimental cell research, vol. 317, (2011), pp. 1261-1269.

[32] Y. P. Chen, P. D. Rekha, A. B. Arun, F. T. Shen and W. A. Lai, "Young Phosphate solubilizing bacteria from subtropical soil and their tricalcium phosphate solubilizing abilities", Applied Soil Ecology, vol. 34, (2006), pp. 33-41.

[33] D. M. Burns and I. R. Beacham, "Nucleotide sequence and transcriptional analysis of the Escherichia coli ushA gene, encoding periplasmic UDP-sugar hydrolase (59-nucleotidase): regulation of the ushA gene, and the signal sequence of its encoded protein product”, Nucleic Acids Res., vol. 14, (1986), pp. 4325-42.

[34] D. J. Korz, U. Rinas, K. Hellmuth, E. A. Sanders and W. D. Deckwer. "Simple fed-batch technique for high cell density cultivation of Escherichia coli", Biotechnol, vol. 39, (1995), pp. 59-65.

[35] G. Zhong, Y. U. Aiping, S. H. I. BingxingI, L. I. U. Yang and W. U. Chutse, "Pilot-scale production and purification of a staphylokinase based fusion protein over-expressed in Escherichia coli”, Front. Biol. China, vol. 4, no. 1, (2009), pp. 75-81.

[36] J.-H. Kim, S.-L. Wong and B.-G. Kim, "Optimization of staphylokinase production in Bacillus subtilis using inducible and constitutive promoters", Biotechnol. Bioprocess Eng., vol. 6, (2001), pp. 167-172.

[37] A. Baez and J. Shiloach, "Escherichia coli avoid high dissolved oxygen stress by activation of SoxRS and manganesesuperoxide dismutase", Microbial Cell Factories, vol. 12, (2013), pp. 23.

[38] A. M. Sanden, I. Prytz, I. Tubulekas, C. Forberg, H. Le, A. Hektor, P. Neubauer, Z. Pragai, C. Harwood, A. Ward, A. Picon, J. T. de Mattos, P. Postma, A. Farewell, T. Nystrom, S. Reeh, S. Pedersen and G. Larsson, "Limiting factors in Escherichia coli fed batch production of recombinant proteins", Biotechnol. Bioeng, vol. 81, (2003), pp. 158-166.

[39] A. De León, A. P. B. de la Rosa, H. Mayani, E. Galindo and O. T. Ramírez, "Two useful dimensionless parameters that combine physiological, operational and bioreactor design parameters for improved control of dissolved oxygen", Biotechnology Letters, vol. 23, (2001), pp. 1051-1056.

[40] M. A. Trujillo-Roldon, C. Pena, O. T. Ramirez and E. Galindo, "Effect of oscillating dissolved oxygen tension on the production of alginate by Azotobacter vinelandii”, Biotechnol. Prog., vol. 17, (2001), pp. $1042-1048$.

[41] Y. Liu, C. Wu, J. Wang, W. Mo and M. Yu, "Codon optimization, expression, purification, and functional characterization of recombinant human IL-25 in Pichia pastoris", Appl Microbiol Biotechnol, vol. 97, (2013), pp. 10349-10358. 
International Journal of Advanced Science and Technology Vol.68 (2014) 